JEMASI: Jurnal Ekonomi Manajemen dan Akuntansi

Vol. 16, No. 2, Juli - Desember 2020

Website: http://ejournal.iba.ac.id/index.php/jemasi

ISSN 1858-2702, e-ISSN 2684-8732

\title{
ANALISIS READINESS FOR CHANGE TERHADAP KINERJA: PERSPEKTIF KARYAWAN KONTRAK DI MASA PANDEMI COVID-19
}

\author{
Masduki Asbari ${ }^{1}$, Dewiana Novitasari ${ }^{2}$, Nelson Silitonga ${ }^{3}$, Didi Sutardi ${ }^{4}$, Gazali $^{5}$ \\ ${ }^{1}$ Sekolah Tinggi Ilmu Ekonomi Insan Pembangunan, kangmasduki.ssi@gmail.com \\ ${ }^{2}$ Sekolah Tinggi Ilmu Ekonomi Insan Pembangunan, dhewiediosa@yahoo.com \\ ${ }^{3}$ Sekolah Tinggi Ilmu Ekonomi Insan Pembangunan, nelsonsilitonga76ueu@gmail.com \\ ${ }^{4}$ Sekolah Tinggi Ilmu Ekonomi Insan Pembangunan, didiskng@gmail.com \\ ${ }^{5}$ Sekolah Tinggi Ilmu Ekonomi Insan Pembangunan, Rahman.gazali@gmail.com
}

\begin{abstract}
This study aimed to measure the effect of transformational leadership on employee performance of the part-time employee of the packaging industry in Tangerang which is mediated by readiness for change. Data collection was done by a simple random sampling technique and the returned and valid questionnaire results were 224 samples. Data processing was used the SEM method with SmartPLS 3.0 software. The results of this study concluded that transformational leadership has no significant effect on employee performance, but transformational leadership has a positive and significant effect on readiness for change. This study conclude also that readiness for change has a positive and significant effect on the relationship between transformational leadership and employee performance. Readiness for change as a full mediator. This new research proposed a model for building employee performance among the part-time employee of the packaging industry in Tangerang through enhancing transformational leadership practice with readiness for change as a mediator. This research could pave the way to improve employee readiness in facing the era of industrial revolution 4.0.
\end{abstract}

Keywords: Employee performance, readiness for change, transformational leadership.

\section{PENDAHULUAN}

Era revolusi industri 4.0 telah menciptakan gelombang dan arus besar perubahan yang tak terperikan sebelumnya. Oleh karena itu, perusahaan harus mempunyai strategi yang mampu melakukan transformasi dan inovasi untuk menghadapinya. Ini agar perusahaan dan bisnis yang telah dibangun tidak tergilas oleh zaman dan terhambat perkembangannya (Jumiran et al., 2020; Novitasari et al., 2020; Nuryanti et al., 2020). Perusahaan harus sudah memiliki sebuah peta perjalanan yang terintegrasi sehingga arah pengembangan bisnis terlihat dengan jelas. Di antara strategi yang mendesak untuk diperhatikan adalah readiness for change (readiness for change) pada diri setiap 
organisasi, lebih-lebih pada organisasi bisnis global. Kompetisi global era kini meniscayakan readiness for changetanpa jeda dari setiap insan insan industry. Kondisi pandemi covid-19 yang sedang melanda dunia, tak terkecuali Indonesia, meniscayakan perubahan situasi dan kondisi bisnis mutakhir (Purwanto, Asbari, Fahlevi, et al., 2020b). Oleh karena itu, manajemen wajib melakukan langkah-langkah praktis dan strategis untuk membawa organisasi keluar dari kubangan krisis yang nyaris menenggelamkan sebagian perusahaan yang tidak menyiapkan diri dengan baik.

Tak dapat dipungkiri, bahwa masyarakat Indonesia memiliki semangat patronasi yang kuat, yakni semangat kepatuhan pada patron, seperti orang tua, atasan, leluhur, dan sejenisnya. Oleh karena itu, memperhatikan praktek kepemimpinan pada setiap unit sosial masyarakat, apalagi pada organsiasi bisnis menjadi penting dan genting (Fikri et al., 2020; Sopa et al., 2020a). Walaupun demikian, di lapangan penelitian ditemukan bahwa praktek kepemimpinan transformasional tidak memberikan pengaruh signifikan terhadap kinerja karyawan, sebagaimana beberapa penelitian berikut ini: (David et al., 2017; Eliyana et al., 2019; Khalifa Elgelal \& Noermijati, 2014; Makena, 2017; Monoyasa et al., 2017; Putri \& Soedarsono, 2017; Siswatiningsih et al., 2019). Berbeda dengan beberapa penelitian mapan lainnya yang menyebutkan bahwa kepemimpinan transformasional berpengaruh signifikan terhadap kinerja karyawan (Asbari, 2019; Fayzhall, Asbari, Purwanto, Goestjahjanti, et al., 2020; Jumiran et al., 2020; Maesaroh et al., 2020; Nugroho et al., 2020; Waruwu et al., 2020; Yanthy et al., 2020). Sehubungan masih ada terjadi research gap di dalam hubungan antara kepemimpinan transformasional, readiness for changedan kinerja karyawan, maka penelitian ini dipandang perlu untuk dilakukan. Misalnya, penelitian (Mahessa \& NRH, 2016) yang menyebutkan bahwa kepemimpinan berpengarauh positif dan significant terhadap kesiapan untuk berubah, sedangkan penelitian (Susyanto, 2019) secara berbeda menemukan bukti bahwa kepemimpinan transformasional tidak memiliki pengaruh signifikan terhadap readiness for changepada karyawan. Oleh karena itu, research gap ini mendorong peneliti untuk mengelaborasi lebih dalam dan meluas tentang hubungan kedua konstruk tersebut.

\section{Kepemimpinan Transformasional}

(Bass \& Avolio, 2000) menyempurnakan teori kepemimpinan transformasional, berdasarkan teori kepemimpinan transformasional sebelumnya dari (Burn, 1978). Para pendukung kepemimpinan transformasional percaya bahwa para pemimpin transformatif menciptakan kepercayaan, kesetiaan, kekaguman, dan rasa hormat di antara para pengikut, dan di antara para pengikut dan para pemimpin, sehingga mereka bersedia secara sukarela untuk mencapai target, tujuan dan visi organisasi. (Robbins, 2001) mengkonfirmasi bahwa pemimpin transformasional adalah mereka yang mampu menginspirasi pengikut mereka untuk mengubah hidup mereka dan bercita-cita untuk tujuan dan visi yang lebih besar. Dalam definisi (Luthans, 2005), pemimpin transformatif mampu mengubah kesadaran 
pengikut mereka, meningkatkan semangat mereka, dan memotivasi mereka untuk melakukan yang terbaik untuk mencapai tujuan organisasi, bukan karena mereka dipaksa untuk, tetapi mereka bersedia. Menurut (Bass \& Avolio, 2000), ada tiga karakteristik pemimpin transformatif, yaitu: pertama, untuk meningkatkan kesadaran pengikut tentang pentingnya proses dan upaya. Kedua, untuk memotivasi pengikut untuk memprioritaskan kepentingan kelompok lebih dari kepentingan individu. Ketiga, untuk mengalihkan kebutuhan pengikut di luar hal-hal materi ke tingkat yang lebih tinggi seperti harga diri dan aktualisasi. Dengan kata lain, (Burn, 1978) menyatakan bahwa pemimpin transformatif adalah orang-orang yang mendorong pengikut untuk bertindak untuk tujuan tertentu yang mewakili nilai-nilai dan motivasi-keinginan dan kebutuhan, aspirasi dan harapan - dari para pemimpin dan pengikut ". Mereka mampu mengubah kesadaran pengikut dan menanamkan nilai-nilai normatif, cita-cita, untuk mencapai moralitas yang lebih tinggi, seperti kesetaraan, kebebasan, keadilan, humanitarianisme, dan kedamaian.

\section{Kesiapan untuk Berubah}

Penelitian yang dilakukan oleh (Holt et al., 2007) menunjukkan bahwa kesiapan untuk perubahan adalah multidimensi yang dipengaruhi oleh keyakinan karyawan bahwa (a) mereka mampu mengimplementasikan perubahan yang diusulkan (yaitu, change efficacy), (b) perubahan yang diusulkan sesuai untuk organisasi (yaitu, appropriateness), (c) para pemimpin berkomitmen untuk perubahan yang diusulkan (yaitu, management support), dan (d) perubahan yang diusulkan bermanfaat bagi organisasi anggota (yaitu, personal benefit). Masih menurut (Holt et al., 2007), indikator yang dapat digunakan untuk mengukur tinggi rendahnya readiness for change karyawan antara lain:

1. Keyakinan karyawan bahwa perubahan yang diusulkan akan tepat bagi organisasi

2. Keyakinan karyawan bahwa organisasi akan mendapatkan keuntungan dari penerapan perubahan

3. Karyawan akan meyakini adanya alasan yang logis untuk berubah dan adanya kebutuhan untuk perubahan yang diusulkan

4. Karyawan berfokus pada manfaat dari perubahan bagi perusahaan

5. Keyakinan karyawan tentang kemampuannya untuk menerapkan perubahan yang diinginkan

6. Karyawan merasa bahwa pemimpin dan manajemen dalam organisasi memiliki komitmen dan mendukung pelaksanaan perubahan yang diusulkan

7. Karyawan merasa bahwa ia akan memperoleh manfaat dari pelaksanaan perubahan yang diusulkan

Untuk mempersiapkan karyawan agar siap berubah pada organisasi maka diperlukan pemahaman mengenai cara-cara yang dapat digunakan dalam menumbuhkan kesiapan untuk berubah. Terdapat dua hal yang dapat dilakukan oleh organisasi yaitu membentuk kesiapan karyawan untuk berubah dan menyelesaikan masalah penolakan 
untuk berubah (Banjongprasert, 2017). (Hadiyani, 2014; Pramadani, 2012) mengungkapkan bahwa komitmen organisasi dapat mempengaruhi kesiapan untuk berubah. Komitmen organisasi merupakan keinginan untuk tetap menjadi anggota organisasi, kepercayaan dan penerimaan nilai-nilai dan tujuan organisasi serta kesediaan untuk berusaha sebaik mungkin demi kepentingan organisasi. Selain itu employee engagement (keterlibatan kerja) memiliki peranan dalam keberhasilan implementasi perubahan organisasi, terutama yang berskala besar yang melibatkan seluruh elemen dari organisasi. Karyawan yang terlibat dalam kegiatan organisasi akan cenderung mendukung jalannya perubahan organisasi dan siap untuk berubah.

\section{Kinerja Karyawan}

Kinerja adalah perilaku bagaimana target berhasil dicapai (Armstrong \& Taylor, 2014). Kinerja merupakan proses berorientasi tujuan yang diarahkan untuk memastikan bahwa proses-proses keorganisasian ada pada tempatnya untuk memaksimalkan produktivitas para karyawan, tim, dan akhirnya, organisasi. Pendapat lain, kinerja merupakan apa yang dilakukan atau tidak dilakukan oleh karyawan (Luthans, 2005). Untuk dapat mengetahui kinerja karyawan pada suatu organisasi maka diperlukan beberapa aspek tertentu. Kinerja dipengaruhi oleh variabel yang terkait dengan pekerjaan meliputi rolestress dan konflik kerja/non-kerja (Babin \& Boles, 1998). Terdapat beberapa kriteria dalam mengukur kinerja, yakni: Kualitas, kuantitas, ketepatan waktu, efektivitas biaya dan hubungan antar personal (Bernardin \& Russel, 1993). Sedangkan (Mathis \& Jackson, 2002) menyebutkan bahwa kinerja karyawan memiliki beberapa elemen, yaitu: kuantitas, kualitas, ketepatan, kehadiran, kemampuan kerjasama, dan kesetiaan.

\section{Pengaruh Kepemimpinan Transformasional terhadap Kinerja Karyawan}

Studi dari (Asbari, et al., 2019; Purwanto, Mayesti Wijayanti, et al., 2019) menunjukkan bahwa kepemimpinan transformasional berhubungan positif dengan kinerja organisasi, dengan mediasi atau tanpa variabel mediasi. Penelitian lain juga menemukan temuan serupa, seperti studi dari (Bernarto et al., 2020). Berdasarkan hasil dan kesimpulan penelitian-penelitian sebelummnya, maka peneliti membuat hipotesis sebagai berikut:

Hipotesis $H_{1}$ : Kepemimpinan transformasional memiliki pengaruh terhadap kinerja karyawan.

\section{Pengaruh Kepemimpinan Transformasional terhadap Readiness for Change}

Penelitian terdahulu menyimpulkan bahwa kepemimpinan transformasional tidak berpengaruh signifikan terhadap readiness for change (Susyanto, 2019). Berbeda dengan kesimpulan penelitian (Mahessa \& NRH, 2016) yang menemukan bukti bahwa kepemimpinan memberikan pengaruh positif dan signifikan terhadap readiness for changepada karyawan BPJS Ketenagakerjaan. Demikian juga kesimpulan dari penelitian 
(Mujiburrahman et al., 2017), (Fitriana \& Sugiyono, 2019), dan (Astuti \& Khoirunnisa, 2018). Berdasarkan hasil kesimpulan penelitian terdahulu, maka penulis menyusun hipotesis kedua sebagai berikut:

Hipotesis $\mathrm{H}_{2}$ : Kepemimpinan transformasional memiliki pengaruh terhadap readiness for change karyawan.

\section{Pengaruh Readiness for Change terhadap Kinerja Karyawan}

Holt, et al (2007) mendefinisikan kesiapan adalah kepercayaan karyawan bahwa mereka mampu melaksanakan perubahan yang diusulkan (self efficacy), perubahan yang diusulkan tepat untuk dilakukan organisasi (appropiateness), pemimpin berkomitmen dalam perubahan yang diusulkan (management support), dan perubahan yang diusulkan akan memberikan keuntungan bagi anggota organisasi (personal benefit). Dari penjelasan Holt, et al (2007) seorang karyawan yang dinyatakan siap untuk berubah akan menunjukkan perilaku menerima, merangkul, dan mengadopsi rencana perubahan yang dilakukan. Sebelum karyawan berada pada posisi siap, karyawan merefleksikan content, context, process, dan atribut individu untuk mempersepsikan dan mempercayai perubahan yang akan dilakukan organisasi. Readiness for changemenjadi faktor penting dalam menciptakan kesuksesan perubahan (Armenakis, et al 1993). Hal ini dapat ditunjukkan bahwa ketika perubahan dilakukan akan muncul dua sikap yaitu positif dan negatif. Sikap positif ditunjukkan dengan adanya readiness for changedan sikap negatif ditunjukkan dengan adanya penolakan terhadap perubahan. Menciptakan sikap positif dalam diri karyawan dapat dilakukan dengan menciptakan readiness for changepada diri karyawan sehingga perubahan yang dilakukan dapat mencapai kesuksesan yang diharapkan.

Hipotesis $H_{3}$ : Readiness for changememiliki pengaruh terhadap kinerja karyawan.

\section{Pengaruh Kepemimpinan Transformasional terhadap Kinerja Karyawan melalui Readiness for changeSebagai Mediator}

Beberapa penelitian menyimpulkan bahwa variabel kepemimpinan transformasional memiliki hubungan yang signifikan terhadap variabel kinerja karyawan melalui readiness for change(Katsaros et al., 2020). Secara parsial, beberapa penelitian lainnya menyebutkan terhadap pengaruh signifikan kepemimpinan transformasional terhadap readiness for change (Astuti \& Khoirunnisa, 2018; Sari, 2018), dan terdapat pengaruh signifikan readiness for changeterhadap kinerja karyawan (Fitriana \& Sugiyono, 2019). Belum banyak penelitian yang memberikan model hubungan mediasi variable readiness for changeterhadap hubungan antara variable kepemimpinan transformasional dan variable kinerja karyawan. Oleh karena itu, penulis berupaya untuk menyusun hipotesisi keempat ini sebagai berikut:

Hipotesis $\mathrm{H}_{4}$ : Kepemimpinan transformasional memiliki pengaruh terhadap kinerja karyawan melalui readiness for change sebagai mediator. 


\section{METODE PENELITIAN}

\section{Definisi Operasional Variabel dan Indikator}

Metode yang digunakan dalam penelitian ini adalah metode kuantitatif. Dilakukan pengumpulan data dengan mengedarkan angket kepada seluruh karyawan industry packaging di Kota Tangerang. Instrumen yang digunakan untuk mengukur transformational leadership diadaptasi dari (Bogler, 2001) dengan menggunakan 5 items (KT1-KT5). Readiness for changediadaptasi dari (Holt et al., 2007) dengan menggunakan 7 items (RFC1-RFC7). Kinerja karyawan diadaptasi dari (Bernardin \& Russel, 1993) dengan menggunakan 6 items (KK1-KK6). Model penelitian bias dilihat sebagaimana pada Gambar 1. Angket didesain tertutup kecuali untuk pertanyaan/pernyataan mengenai identitas responden yang berupa angket semi terbuka. Tiap item pertanyaan/pernyataan tertutup diberikan lima opsi jawaban, yaitu: sangat setuju (SS) skor 5, setuju (S) skor 4, netral/ ragu-ragu (N) skor 3, tidak setuju (TS) skor 2, dan sangat tidak setuju (STS) skor 1. Metode untuk mengolah data adalah dengan PLS dan menggunakan software SmartPLS versi 3.0 sebagai toolnya.

\section{Populasi dan Sampel}

Populasi dalam penelitian ini adalah karyawan dari salah satu industri packaging di Kota Tangerang yang jumlahnya 227 orang. Kuesioner disebarkan dengan teknik simple random sampling. Hasil kuesioner yang kembali sebanyak valid adalah 143 sampel. Jadi jumlah sampel adalah $71.11 \%$ dari jumlah populasi.

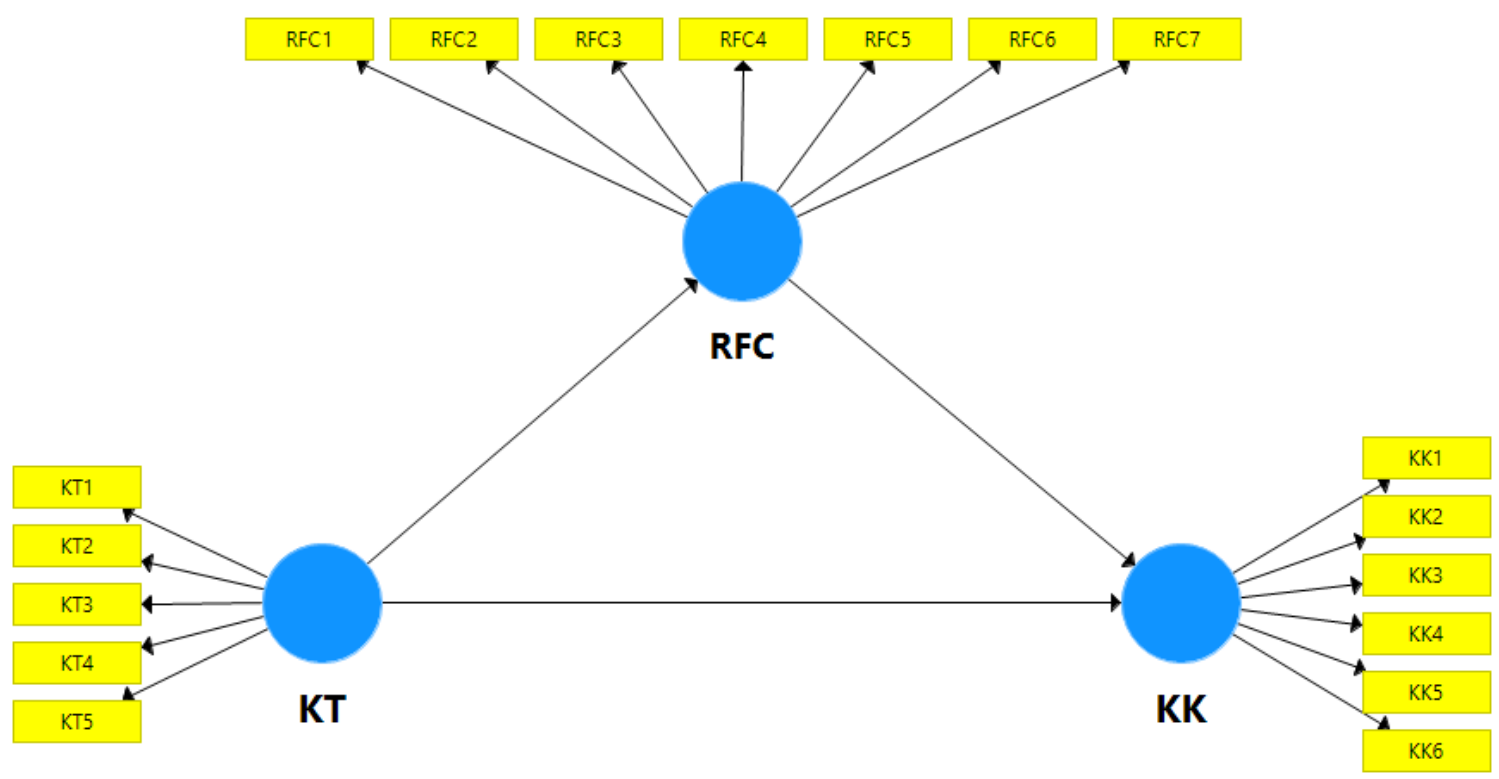

Gambar 1. Model Penelitian 


\section{ANALISIS DAN HASIL PEMBAHASAN \\ Deskripsi Sampel}

Table 1. Deskripsi Sampel

\begin{tabular}{llll}
\hline Kriteria & & Jumlah & \% \\
\hline Usia (per November 2019) & $<20$ tahun & 36 & $25.4 \%$ \\
& $20-30$ tahun & 67 & $46.6 \%$ \\
& $>30$ tahun & 40 & $28.0 \%$ \\
Masa kerja sebagai karyawan & $<1$ tahun & 51 & $35.7 \%$ \\
kontrak & $1-2$ tahun & 69 & $48.5 \%$ \\
& $>3$ tahun & 23 & $15.8 \%$ \\
Ijazah tertinggi & $\geq$ S1 & 0 & $0 \%$ \\
& SLTA & 125 & $87.5 \%$ \\
& SLTP & 18 & $12.5 \%$ \\
\hline
\end{tabular}

\section{Hasil Uji Validitas dan Reliabilitas Indikator Penelitian}

Tahap pengujian model pengukuran meliputi pengujian validitas konvergen, validitas diskriminan. Sementara untuk menguji reliabilitas konstruk digunakan nilai cronbach's alpha dan composite reliability. Hasil analisis PLS dapat digunakan untuk menguji hipotesis penelitian jika seluruh indikator dalam model PLS telah memenuhi syarat validitas konvergen, validitas deskriminan dan uji reliabilitas.

\section{Pengujian Validitas Konvergen}

Uji validitas konvergen dilakukan dengan melihat nilai loading factor masingmasing indikator terhadap konstruknya. Pada sebagian besar referensi, bobot faktor sebesar 0.5 atau lebih dianggap memiliki validasi yang cukup kuat untuk menjelaskan konstruk laten (Chin, 1998; Ghozali, 2014; Hair et al., 2010). Pada penelitian ini batas minimal besarnya loading factor yang diterima adalah 0.5, dengan syarat nilai AVE setiap konstruk > 0.5 (Ghozali, 2014). Setelah melalui pengolahan SmartPLS 3.0, ternyata seluruh indikator telah memiliki nilai loading factor di atas 0.5 dan bahkan sudah sesuai dengan syarat nilai AVE di atas 0.5. Model fit atau valid dari penelitian ini bias dilihat pada Gambar 2. Jadi dengan demikian, validitas konvergen dari model penelitian ini sudah memenuhi syarat. Nilai loadings, cronbach's alpha, composite reliability dan AVE setiap konstruk selengkapnya dapat dilihat Tabel 2 berikut: 


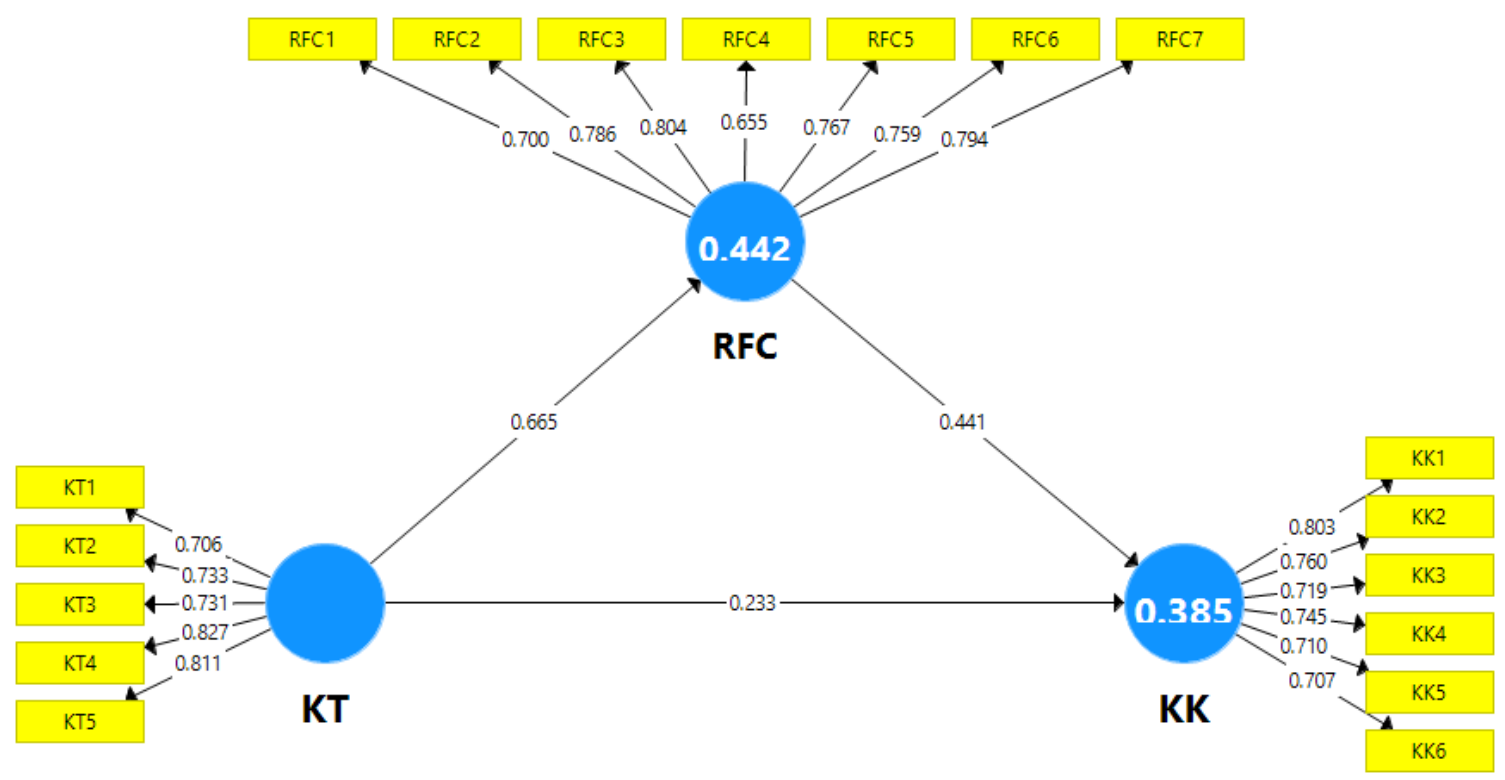

Gambar 2. Model Penelitian Valid

Tabel 2. Items Loadings, Cronbach's Alpha, Composite Reliability, and Average Variance Extracted (AVE)

\begin{tabular}{|c|c|c|c|c|c|}
\hline Varables & Items & Loadings & $\begin{array}{l}\text { Cronbach's } \\
\text { Alpha }\end{array}$ & $\begin{array}{l}\text { Composite } \\
\text { Reliability }\end{array}$ & AVE \\
\hline Kepemimpinan & KT1 & 0.706 & 0.820 & 0.874 & 0.582 \\
\hline \multirow[t]{4}{*}{ Transformasional (KT) } & KT2 & 0.733 & & & \\
\hline & KT3 & 0.731 & & & \\
\hline & KT4 & 0.827 & & & \\
\hline & KT5 & 0.811 & & & \\
\hline \multirow{7}{*}{$\begin{array}{l}\text { Readiness fo Change } \\
\text { (RFC) }\end{array}$} & RFC1 & 0.700 & 0.873 & 0.902 & 0.569 \\
\hline & RFC2 & 0.786 & & & \\
\hline & RFC3 & 0.804 & & & \\
\hline & RFC4 & 0.655 & & & \\
\hline & RFC5 & 0.767 & & & \\
\hline & RFC6 & 0.759 & & & \\
\hline & RFC7 & 0.794 & & & \\
\hline \multirow{6}{*}{$\begin{array}{l}\text { Kinerja Karyawan } \\
(\mathrm{KK})\end{array}$} & KK1 & 0.803 & 0.837 & 0.880 & 0.550 \\
\hline & KK2 & 0.760 & & & \\
\hline & KK3 & 0.719 & & & \\
\hline & KK4 & 0.745 & & & \\
\hline & KK5 & 0.710 & & & \\
\hline & KK6 & 0.707 & & & \\
\hline
\end{tabular}


Tabel 3. Discriminant Validity

\begin{tabular}{llll}
\hline Variables & KK & KT & RFC \\
\hline & & & \\
Kinerja Karyawan (KK) & $\mathbf{0 . 7 4 1}$ & & \\
Kepemimpinan Transformasional (KT) & 0.526 & $\mathbf{0 . 7 6 3}$ & \\
Readiness for Change $(R F C)$ & 0.596 & 0.665 & $\mathbf{0 . 7 5 4}$ \\
\hline
\end{tabular}

Tabel 4. Collinearity Statistics (VIF)

\begin{tabular}{lll}
\hline Variables & $\begin{array}{l}\text { Readiness for Change } \\
(\text { RFC })\end{array}$ & $\begin{array}{l}\text { Kinerja } \\
\text { Karyawan (KK) }\end{array}$ \\
\hline & & 1.791 \\
Readiness for Change $(R F C)$ & & 1.791 \\
Kepemimpinan Transformasional (KT) & 1.000 & \\
\hline
\end{tabular}

\section{Pengujian Validitas Deskriminan}

Discriminant validity dilakukan untuk memastikan bahwa setiap konsep dari masing-masing variabel laten berbeda dengan variabel laten lainnya. Model mempunyai discriminant validity yang baik jika nilai kuadrat AVE masing-masing konstruk eksogen (nilai pada diagonal) melebihi korelasi antara konstruk tersebut dengan konstruk lainnya (nilai di bawah diagonal) (Ghozali, 2014) . Hasil pengujian discriminant validity adalah dengan menggunakan nilai kuadrat AVE, yakni dengan melihat Fornell-Larcker Criterion Value diperoleh sebagaimana ditunjukkan pada Tabel 3. Hasil uji validitas deskriminan pada tabel 3 di atas menunjukkan bahwa seluruh konstruk telah memiliki nilai akar kuadrat AVE di atas nilai korelasi dengan konstruk laten lainnya (melalui kriteria Fornell-Larcker). Demikian juga nilai cross-loading seluruh item dari suatu indikator lebih besar dari item indikator lainnya sebagaimana disebut pada Tabel 4, sehingga dapat disimpulkan bahwa model telah memenuhi validitas deskriminan (Fornell \& Larcker, 1981). Selanjutnya, evaluasi kolinearitas dilakukan untuk mengetahui apakah ada kolinearitas dalam model. Untuk menemukan collinearity, diperlukan penghitungan VIF dari setiap konstruk. Jika skor VIF lebih tinggi dari 5, maka model tersebut memiliki collinearity (Hair et al., 2014). Sebagaimana ditunjukkan pada Tabel 4, semua skor VIF lebih kecil dari 5, artinya bahwa model ini tidak memiliki masalah collinearity.

\section{Pengujian Reliabilitas Konstruk}

Reliabilitas konstruk dapat dinilai dari nilai cronbach's alpha dan composite reliability dari masing-masing konstruk. Nilai composite reliability dan cronbach's alpha yang disarankan adalah lebih dari 0.7 (Ghozali, 2014). Hasil uji reliabilitas pada tabel 2 di 
atas menunjukkan bahwa seluruh konstruk telah memiliki nilai composite reliability dan cronbach's alpha lebih besar dari 0.7 (> 0.7). Kesimpulannya, seluruh konstruk telah memenuhi reliabilitas yang dipersyaratkan.

\section{Pengujian Hipotesis}

Pengujian hipotesis dalam PLS disebut juga sebagai uji inner model. Uji ini meliputi uji signifikansi pengaruh langsung dan tidak langsung serta pengukuran besarnya pengaruh variabel eksogen terhadap variabel endogen. Untuk mengetahui pengaruh kepemimpinan transformasional terhadap kinerja karyawan dengan melalui readiness for changesebagai variable mediasi dibutuhkan uji pengaruh langsung dan tidak langsung. Uji pengaruh dilakukan dengan menggunakan uji t-statistik dalam model analisis partial least squared (PLS) dengan menggunakan bantuan software SmartPLS 3.0. Dengan teknik boothstrapping, diperoleh nilai $R$ Square dan nilai uji signifikansi sebagaimana Tabel 5 dan Tabel 6 di bawah ini:

Tabel 5. Nilai $R$ Square

\begin{tabular}{lcl}
\hline & R Square & R Square Adjusted \\
\hline Readiness for Change $($ RFC $)$ & 0.442 & 0.438 \\
Kinerja Karyawan $(\mathrm{KK})$ & 0.385 & 0.376 \\
\hline
\end{tabular}

Tabel 6. Hypotheses Testing

\begin{tabular}{llccccc}
\hline $\begin{array}{l}\text { Hypot } \\
\text { heses }\end{array}$ & Relationship & Beta & SE & T Statistics & P-Values & Decision \\
\hline H1 & KT -> KK & 0.233 & 0.079 & 2.953 & 0.003 & Supported \\
H2 & KT -> RFC & 0.665 & 0.045 & 14.758 & 0.000 & Supported \\
& & & & & & \\
H3 & RFC -> KK & 0.441 & 0.080 & 5.508 & 0.000 & Supported \\
& KT $>$ RFC $\rightarrow$ & 0.293 & 0.056 & 5.215 & 0.000 & Supported \\
& KK & & & & & \\
\hline
\end{tabular}

Berdasarkan Tabel 5 di atas, nilai $R$ Square readiness for change (RFC) sebesar 0.442 yang berarti bahwa variable readiness for change (RFC) mampu dijelaskan oleh variabel kepemimpinan transformasional (KT) sebesar $44.2 \%$, sedangkan sisanya sebesar $55.8 \%$ dijelaskan oleh variabel lain yang tidak dibahas dalam penelitian ini. Nilai $R$ Square kinerja karyawan (KK) sebesar 0.385 yang berarti bahwa variabel kinerja karyawan (KK) mampu dijelaskan oleh variabel kepemimpinan transformasional (KT) dan readiness for change (RFC) sebesar $38.5 \%$, sedangkan sisanya sebesar $61.5 \%$ dijelaskan oleh variabel 
lain yang tidak dibahas dalam penelitian ini. Sedangkan Tabel 6 menampilkan $t$-statistics dan $p$-values yang menunjukkan pengaruh antar variable penelitian yang telah disebutkan.

\section{Pembahasan}

Berdasarkan penghitungan statistic yang diringkas pada Tabel 6 di atas, disimpulkan bahwa kepemimpinan transformasional berpengaruh signifikan terhadap kinerja karyawan kontrak di industri. Terbukti dengan nilai t-statistics 2.953 lebih besar dari 1.96 dan nilai p-values sebesar 0.003 lebih kecil dari 0.05. Artinya, hipotesis pertama (H1) diterima. Temuan ini berkesesuaian dengan hasil penelitian sebelumnya dari (Asbari, 2019; Asbari, Fayzhall, et al., 2020). Artinya, gaya kepemimpinan yang dipraktikkan di dalam organisasi sudah cukup baik dan mampu men-drive kinerja karyawan kontrak.

Berdasarkan penghitungan statistic yang diringkas pada Tabel 6 di atas, disimpulkan bahwa kepemimpinan transformasional secara positif dan signifikan mempengaruhi readiness for change pada karyawan kontrak di industri. Terbukti dengan nilai $t$-statistics 14.758 lebih besar dari 1.96 dan nilai $p$-values sebesar 0.000 lebih kecil dari 0.05. Artinya, hipotesis kedua (H2) diterima. Temuan ini sesuai dengan kesimpulan temuan empiris dan teoritis dari penelitian sebelumnya dari (Astuti \& Khoirunnisa, 2018; Fitriana \& Sugiyono, 2019; Mahessa \& NRH, 2016) yang mengkonfirmasi bahwa kepemimpinan transformasional secara signifikan mempengaruhi readiness for change pada karyawan kontrak.

Berdasarkan penghitungan statistic yang diringkas pada Tabel 6 di atas, disimpulkan bahwa readiness for change secara positif dan signifikan mempengaruhi kinerja karyawan di industri. Terbukti dengan nilai t-statistics 5.508 lebih besar dari 1.96 dan nilai $p$-values sebesar 0.000 lebih kecil dari 0.05. Artinya, hipotesis ketiga (H3) diterima. Kesimpulan penelitian ini mendukung apa yang telah ditemukan pada penelitian sebelumnya, bahwa readiness for changeberpengaruh positif dan signifikan terhadap kinerja (Banjongprasert, 2017; Katsaros et al., 2020).

Berdasarkan penghitungan statistic yang diringkas pada Tabel 6 di atas, disimpulkan bahwa readiness for change secara positif dan signifikan mempengaruhi kinerja karyawan melalui readiness for changepada karyawan kontrak di industri. Terbukti dengan nilai $t$-statistics 5.215 lebih besar dari 1.96 dan nilai $p$-values sebesar 0.000 lebih kecil dari 0.05. Artinya, hipotesis ketiga (H4) diterima. Kesimpulan penelitian ini mendukung apa yang telah ditemukan pada penelitian sebelumnya oleh (Katsaros et al., 2020) yang menyimpulkan bahwa readiness for change mampu memediasi hubungan pengaruh kepemimpinan terhadap kinerja karyawan. Pada penelitian ini, peran readiness for change adalah partial mediation. 


\section{KESIMPULAN DAN SARAN}

\section{Kesimpulan}

Berdasarkan hasil penelitian ini, disimpulkan bahwa kepemimpinan transformasional memberikan pengaruh yang signifikan terhadap tinggi-rendahnya tingkat kinerja karyawan kontrak di industry packaging. Ditambah lagi, keyakinan dan semangat readiness for change pada diri karyawan mampu meningkatkan kinerja. Ada hal menarik yang bias diperhatikan dari hasil penelitian ini, bahwa di era pandemic Covid19 ini, praktek kepemimpinan transformasional sangat signifikan berpengaruh terhadap kinerja karyawan. Motivasi dan keteladanan pemimpin di industry dipersepsi oleh karyawan kontrak secara positif dan mampu menggerakkan karyawan untuk meningkatkan kinerja, walaupun pada kondisi berat di masa pandemic ini. Di sisi lain, kepemimpinan transformasional juga mampu memberikan pengaruh yang positif dan signifikan terhadap readiness for changepada diri karyawan di masa pandemic covid-19 ini, mengapa demikian? Jawabannya, di dalam praktek kepemimpinan, terdapat dimensi keteladan dan mempengaruhi yang sangat dominan. Briefing dan sesi rapat yang kerap diadakan oleh pemimpin mampu memunculkan kesadaran dan keyakinan kuat kepada karyawan bahwa pandemic covid-19 ini akan bisa berakhir dan normal kembali. Di samping itu, motivasi yang diberikan oleh pemimpin transformasional memberikan keyakinan bahwa pasca pandemic, perusahaan akan memiliki kinerja lebih lagi karena mampu melihat peluang-peluang baru di masa depan. Di samping itu, penelitian ini menemukan bukti bahwa readiness for changemampu menjadi mediasi penuh terhadap hubungan antara kepemimpinan transformasional dan kinerja karyawan.

\section{REFERENSI}

Agistiawati, E., Asbari, M., Basuki, S., Yuwono, T., \& Chidir, G. (2020). Exploring the Impact of Knowledge Sharing and Organizational Culture on Teacher Innovation Capability. International Journal of Science and Management Studies (IJSMS), 3(3), 62-77. http://www.ijsmsjournal.org/current-issue.html

Armstrong, M., \& Taylor, S. (2014). Human Resource Management Practice. Ashford Colour Press Ltd.

Asbari, M. (2015). Fokus Satu Hebat. Penerbit Dapur Buku.

Asbari, M. (2019). Pengaruh kepemimpinan transformasional dan iklim organisasi terhadap kinerja dosen. JOCE IP, 13(2), 172-186. http://jurnal.ipem.ac.id/index.php/joce-ip/article/view/187

Asbari, M., Fayzhall, M., Goestjahjanti, F. S., Winanti, Yuwono, T., Hutagalung, D., Basuki, S., Maesaroh, S., Mustofa, Chidir, G., Yani, A., \& Purwanto, A. (2020). Peran Kepemimpinan Transformasional Dan Organisasi Pembelajaran Terhadap Kapasitas Inovasi Sekolah. EduPsyCouns: Journal of Education, Psychology and Counseling, 2(1), 6724-6748. https://ummaspul.e-journal.id/Edupsycouns/article/view/421

Asbari, M., Hyun, C. C., Wijayanti, L. M., WINANTI, W., Fayzhall, M., \& Putra, F. (2020). Hard Skills Dan Soft Skills: Apa Membangun Inovasi Guru Sekolah Islam? Journal EVALUASI, 4(1), 143. https://doi.org/10.32478/evaluasi.v4i1.362

Astuti, E., \& Khoirunnisa, R. M. (2018). Pengaruh Employee Engagement, Komitmen Organisasi, Dan Kepemimpinan Transformasional Terhadap Kesiapan Untuk Berubah (Readiness For 
Change) Pada Karyawan Universitas Ahmad Dahlan. JURNAL FOKUS, 8(1), 47-66.

Babin, B. J., \& Boles, J. S. (1998). Employee behavior in a service environment: A model and test of potential differences between men and women. Journal of Marketing, 62(2), 77-91. https://doi.org/10.2307/1252162

Banjongprasert, J. (2017). An Assessment of Change-Readiness Capabilities and Service Innovation Readiness and Innovation Performance : Empirical Evidence from MICE Venues. IJEM International Journal of Economics and Management, 11, 1-17.

Bass, B., \& Avolio, B. (2000). Technical Report,Leader form, rater form, and Scoring Key of MLQ From $5 x$-Short. Mind Garden, Inc.

Bernardin, H., \& Russel, J. (1993). Human Resource Management: An Experimental Approach. Mc Graw Hill Companies.

Bernarto, I., Bachtiar, D., Sudibjo, N., Suryawan, I. N., Purwanto, A., \& Asbari, M. (2020). Effect of transformational leadership, perceived organizational support, job satisfaction toward life satisfaction: Evidences from indonesian teachers. International Journal of Advanced Science and Technology, 29(3), 5495-5503. http://sersc.org/journals/index.php/IJAST/article/view/6057

Bogler, R. (2001). The influence of leadership style on teacher job satisfaction. Educational Administration Quarterly, 37(5), 662-683. https://doi.org/10.1177/00131610121969460

Burn, J. (1978). Leadership. Harper.

Chin, W. (1998). The Partial Least Squares Approach to Structural Equation Modeling (E. Modern Methods for Business Research, In: G. A. Marcoulides (ed.)). Lawrence Erlbaum Associates Publisher.

David, S., Armanu, \& Afnan, T. E. (2017). The Effects of Transformational Leadership and Personality on Employee Performance in Nissan Malang Mediated by Organizational Commitment. RJOAS, 3(19), 197-210. https://doi.org/https://doi.org/10.18551/rjoas.201701.21

Eliyana, A., Ma'arif, S., \& Muzakki. (2019). Job satisfaction and organizational commitment effect in the transformational leadership towards employee performance. European Research on Management and Business Economics, 25(3), 144-150. https://doi.org/10.1016/j.iedeen.2019.05.001

Fayzhall, M., Asbari, M., Purwanto, A., Goestjahjanti, F. S., Yuwono, T., Radita, F. R., Yulia, Y., Cahyono, Y., \& Suryani, P. (2020). Transformational versus Transactional Leadership: Manakah yang Mempengaruhi Kepuasan Kerja Guru? EduPsyCouns: Journal of Education, Psychology and Counseling, 2(1), 256-275. https://ummaspul.ejournal.id/Edupsycouns/article/view/463

Fikri, M. A. A., Asbari, M., Purwanto, A., Nugroho, Y. A., Waruwu, H., Fauji, A., Shobihi, A. W., Singgih, E., Sudiyono, R. N., Agistiawati, E., \& Dewi, W. R. (2020). A Mediation Role of Organizational Learning on Relationship of Hard Skills, Soft Skills, Innovation and Performance: Evidence at Islamic School. EduPsyCouns: Journal of Education, Psychology and Counseling, 2(1), 398-423. https://ummaspul.e-journal.id/Edupsycouns/article/view/498

Fitriana, R., \& Sugiyono. (2019). Kesiapan berubah pada sekretariat jenderal kementerian kelautan dan perikanan republik indonesia. IKRAITH EKONOMIKA VOL, 2(2), 42-51.

Fornell, C., \& Larcker, D. F. (1981). Evaluating Structural Equation Models with Unobservable Variables and Measurement Error. Journal of Marketing Research, 18(1), 39. https://doi.org/10.2307/3151312

Ghozali, I. (2014). Structural Equation Modeling, Metode Alternatif dengan Partial Least Square $(P L S)$ (4th ed.). Badan Penerbit Universitas Diponegoro.

Hadiyani, S. (2014). Peranan Komitmen Organisasi dan Employee Engagement terhadap Kesiapan Karyawan untuk Berubah. JURNAL PSIKOLOGI, 41(1), 17-33. 
Hair, J. F., Black, W. C., Babin, B. J., \& Anderson, R. E. (2010). Multivariate Data Analysis (7th ed.). Pearson Prentice Hall.

Hair, J. F., Hult, G. T., Ringle, C. M., \& Sarstedt, M. (2014). A primer partial least squaresstructural equation modeling (PLS-SEM). SAGE Publications.

Holt, D. T., Armenakis, A. A., Feild, H. S., \& Harris, S. G. (2007). The Journal of Applied Behavioral Science The Systematic Development of a Scale. Feild and Stanley G. Harris Journal of Ap, 43, 232. https://doi.org/10.1177/0021886306295295

Jumiran, Novitasari, D., Nugroho, Y. A., Sutardi, D., Sasono, I., \& Asbari, M. (2020). Pengaruh Dimensi Kepemimpinan Transformasional terhadap Kepuasan Kerja dan Komitmen Organisasional: Studi Kasus pada Dosen Perguruan Tinggi Swasta. EduPsyCouns: Journal of Education, Psychology and Counseling, 2(1), 600-621. https://ummaspul.ejournal.id/Edupsycouns/article/view/555

Katsaros, K. K., Tsirikas, A. N., \& Kosta, G. C. (2020). The impact of leadership on firm financial performance: the mediating role of employees' readiness to change. Leadership \& Organization Development Journal, 41(3), 333-347. https://doi.org/https://doi.org/10.1108/LODJ-02-2019-0088

Khalifa Elgelal, K. S., \& Noermijati, N. (2014). The Influences of Transformational Leaderships on Employees Performance (A Study of the Economics and Business Faculty Employee at University of Muhammadiyah Malang). Asia Pacific Management and Business Application, 3(1), 48-66. https://doi.org/10.21776/ub.apmba.2014.003.01.4

Luthans, F. (2005). Perilaku Organisasi (Edisi Kese). Penerbit ANDI.

Maesaroh, S., Asbari, M., Hutagalung, D., Agistiawati, E., Basuki, S., Radita, F. R., Nurasiah, Yulia, Y., Singgih, E., \& Chidir, G. (2020). Pengaruh Religiusitas dan Kepemimpinan Transformasional terhadap Kinerja Guru melalui Mediasi Organizational Citizenship Behavior. EduPsyCouns: Journal of Education, Psychology and Counseling, 2(1), 276-290. https://ummaspul.e-journal.id/Edupsycouns/article/view/473

Mahessa, N. F., \& NRH, F. (2016). Gaya Kepemimpinan Melayani dan Kesiapan untuk Berubah pada Karyawan BPJS Ketenagakerjaan. Jurnal Empati, 5(1), 113-116.

Makena, J. E. (2017). Pengaruh Kepemimpinan Transformasional Terhadap Kinerja Organisasi Melalui Pembelajaran Organisasi dan Inovasi Pada Hotel Prama Sanur Beach Bali. JAGADHITA:Jurnal Ekonomi \& Bisnis, 4(2), 76-88. https://doi.org/10.22225/jj.4.2.135.7688

Mathis, \& Jackson. (2002). Manajemen Sumber Daya Manusia (Pertama). Salemba Empat.

Monoyasa, M. W., Sularso, R. A., \& Prihatini, D. (2017). Pengaruh Gaya Kepemimpinan Transformasional Kepala Sekolah Terhadap Kinerja Guru Sekolah Dasardengan Motivasidan Inovasi Guru Sebagai Variabel Intervening Dieks Kota Administratif. JURNAL RELASI STIE MANDALA JEMBER, 13(2), 315-335. http://jurnal.stiemandala.ac.id/index.php/relasi/article/download/120/107

Mujiburrahman, Asmony, T., \& Husnan, H. (2017). Pengaruh Kepemimpinan Transformasional Dan Iklim Psikologis Terhadap Kesiapan Untuk Berubah Karyawan Puskesmas Kabupaten Lombok Barat Dalam Rangka Akreditasi Dan Komitmen Afektif Sebagai Variabel Intervening. JURNAL MAGISTER MANAJEMEN, 6(2), 1-19. https://doi.org/JURNAL MAGISTER MANAJEMEN

Novitasari, D., Asbari, M., Wijaya, M. R., \& Yuwono, T. (2020). Effect of Organizational Justice on Organizational Commitment: Mediating Role of Intrinsic and Extrinsic Satisfaction. International Journal of Science and Management Studies (IJSMS), 3(3), 96-112. http://www.ijsmsjournal.org/current-issue.html

Nugroho, Y. A., Asbari, M., Purwanto, A., Basuki, S., Sudiyono, R. N., Fikri, M. A. A., Hulu, P., Mustofa, Chidir, G., Suroso, \& Xavir, Y. (2020). Transformational Leadership and 
Employees' Performance: the Mediating Role of Motivation and Work Environment. EduPsyCouns: Journal of Education, Psychology and Counseling, 2(1), 438-460. https://ummaspul.e-journal.id/Edupsycouns/article/view/507

Nuryanti, Y., Novitasari, D., Nugroho, Y. A., Fauji, A., Gazali, \& Asbari, M. (2020). Meningkatkan Komitmen Organisasional Dosen: Analisis Pengaruh Kepemimpinan Perguruan Tinggi dan Kepuasan Intrinsik \& Ekstrinsik Dosen. EduPsyCouns: Journal of Education, Psychology and Counseling, 2(1), 561-581. https://ummaspul.ejournal.id/Edupsycouns/article/view/551

Pramadani, A. B. (2012). Hubungan antara Komitmen Organisasi dengan Kesiapan untuk Berubah pada Karyawan Divisi Enterprise Service (DES) Telkom Ketintang Surabaya. Jurnal Psikologi Industri Dan Organisasi, 1(03), 112-119.

Purwanto, A., Asbari, M., Budi Santoso, P., Mayesti Wijayanti, L., Chi Hyun, C., Berman Sihite, O., \& Prameswari Saifuddin, M. (2020a). Pengaruh Gaya Kepemimpinan Partisipatif dan Otokratis Terhadap Kinerja Sistem Jaminan Halal HAS 23000 Pada Industri Makanan Kemasan. Edumaspul - Jurnal Pendidikan, 4(1). https://www.researchgate.net/publication/339470652_Pengaruh_Gaya_Kepemimpinan_Part isipatif_dan_Otokratis_Terhadap_Kinerja_Sistem_Jaminan_Halal_HAS_23000_Pada_Indu stri_Makanan_Kemasan

Purwanto, A., Pramono, R., Asbari, M., Santoso, P. B., Wijayanti, L. M., Choi, C. H., \& Putri, R. S. (2020). Studi Eksploratif Dampak Pandemi COVID-19 Terhadap Proses Pembelajaran Online di Sekolah Dasar. EduPsyCouns: Journal of Education, Psychology and Counseling, 2(1), 1-12. https://ummaspul.e-journal.id/Edupsycouns/article/view/397

Putri, M. D., \& Soedarsono, D. K. (2017). Pengaruh Kepemimpinan Transformasional Dan Employee Engagement Terhadap Kinerja Karyawan Direktorat Solution Operation Telkomsigma. E-Proceeding of Management :, 4(3), 2541-2546.

Robbins, S. P. (2001). Organizational Behavior: Concept, Controversies, Aplications (8th Editio). Indeks Kelompok Gramedia.

Sari, P. O. (2018). Pengaruh Gaya Kepemimpinan Transformasional, Komitmen Afektif, Komitmen Kontinuans dan Komitmen Normatif terhadap Kesiapan Berubah (Studi Pada Bank BRI Kantor Wilayah Yogyakarta). EXERO: Journal of Research in Business and Economics, 1(1), 68-89. https://doi.org/10.24071/exero.2018.010104

Setyowati Putri, R., Purwanto, A., Pramono, R., Asbari, M., Mayesti Wijayanti, L., \& Chi Hyun, C. (2020). Impact of the COVID-19 Pandemic on Online Home Learning: An Explorative Study of Primary Schools in Indonesia. International Journal of Advanced Science and Technology, 29(5), http://sersc.org/journals/index.php/IJAST/article/view/13867

Siswatiningsih, I., Raharjo, K., \& Prasetya, A. (2019). Pengaruh Kepemimpinan Transformasional Dan Transaksional Terhadap Budaya Organisasi, Motivasi Kerja, Komitmen Oganisasional Dan Kinerja Karyawan. Jurnal Bisnis Dan Manajemen, 5(2), 146-157. https://doi.org/10.26905/jbm.v5i2.2388

Sopa, A., Asbari, M., Purwanto, A., Budi Santoso, P., Mustofa, Hutagalung, D., Maesaroh, S., Ramdan, M., \& Primahendra, R. (2020b). Hard skills versus soft skills: Which are more important for indonesian employees innovation capability. International Journal of Advanced Science and Technology, 29(3), 6431-6453. http://sersc.org/journals/index.php/IJAST/article/view/7233

Sudiyono, R. N., Fikri, M. A. A., Asbari, M., Suroso, Nugroho, Y. A., \& Singgih, E. (2020). The Role of Employee Engagement in the Relationship between Authentic Leadership, Talent Management and Job Satisfaction. International Journal of Advanced Science and Technology, 29(5), 11809-11836. http://sersc.org/journals/index.php/IJAST/article/view/25377 
Susyanto, H. (2019). Pengaruh Kepemimpinan, Keterlibatan Karyawan dan Kepuasan Kerja terhadap Kesiapan untuk Berubah dalam Menghadapi Perubahan Organisasi. Jurnal Ekonomi, Bisnis, Dan Akuntansi (JEBA), 21(1).

Yuwono, T., Novitasari, D., Hutagalung, D., Sasono, I., Silitonga, N., \& Asbari, M. (2020). Peran Organizational Justice terhadap Komitmen Organisasional: Analisis Mediasi Kepuasan Kerja Dosen Perguruan Tinggi Swasta. EduPsyCouns: Journal of Education, Psychology and Counseling, 2(1), 582-599. https://ummaspul.e-journal.id/Edupsycouns/article/view/550 